\title{
Extraction, Isolation and Identification of Some Natural Bioactive Marine Products from Squilla mantis (Stomatopoda-Squillidae) with Special Reference to Seasonal Variation of Marine Algae diversity
} Amr M. Nasef

Marine Biology Section, Zoology Department, Faculty of Science, Al-Azhar University, Nasr City - Cairo - Egypt.

E.mail: marine@azhar.edu.eg, Mobile:00201009324339

\begin{abstract}
Background: Marine algae important in food chain, productivity and marine ecosystem, Also Squilla mantis is healthy human food. Aim of the work: To identify some biologically active natural marine products, and screening its bioactivity, as well as discover the seasonal variation diversity of associated marine algae, for its role in the marine food chain.

Materials and methods: The squills were collected and marine macroalgae associated with it. Also, some biologically active marine natural products were extracted and identified from shell extract to examine its effect on some microbs and laryngeal cancer.

Results: The results showed a seasonal variation in diversity of marine algae, which indicated the effect of seasonal change food availability and environmental yield. The results of antimicrobial activity of Squilla mantis shell extract indicated an important effect differences between the groups treated with shell extract $(1.5,2.5$, and $5 \mathrm{mg} / \mathrm{mL})$ compared to the control. Also, evaluation of viability of Hep-2 cell line post treatment with shell extract of Squilla mantis using sufranin uptake assay as (MTT) uptake and microscopic examination indicated a significant difference between the groups treated with shell extract compared to the control group. Cell viability decreased depending on dose or concentration. The shell extract inhibited the proliferation of a larynx cancer cell line in a dose dependent manner.

Conclusion: The present study showed that, there are seasonal variation in marine algae diversity, which affect on productivity and food availability. Also, there are importance natural bioactive marine products from Squilla mantis shell extract.
\end{abstract}

Key words: Benthos, Extract, Marine Macroalgae, Mediterranean Sea, Shell, Squilla mantis

\section{INTRODUCTION}

Although the impact of seasonal changes on the environment and marine organisms has been explored in multiple papers, the area is still vast and requires more new research from various perspectives, especially in light of the rise of climate change. According to Whiteley (1), who researched the physiological and ecological responses of crustaceans, the species most at danger are entirely marine and have limited physiological capacities to adapt to environmental change. As a result of these changes, species survival, range, and abundance may be impacted.

According to Akram Ullah et al. ${ }^{(2)}$, the biochemical composition of different species vary. Despite the fact that no data on the elements that may influence it is collected. The environment is unstable along the Mediterranean Sea's south coast, (3). Ecological variables have influenced the physiology and distribution of marine creatures through physical and chemical stress, according to Davenport et al. ${ }^{(4) .}$

Bridget $\boldsymbol{e t} \boldsymbol{a l} .^{(5)}$ investigated the effects of the environment on fished lobsters and crabs, and found that: "Climate change's consequences, such as ocean warming and acidity, are fast-growing and rapidly changing fields of inquiry". The photosynthetic activity of aquatic flora, temperature, salinity, and the amount of organic components all have a significant impact ${ }^{(6)}$.

The findings of Velasco et al. ${ }^{(7)}$ showed that abiotic stressors (temperature, $\mathrm{pH}$, etc.) have an impact on marine creatures (fauna or flora) in many of the physiological aspects that influence the performance and composition of the aquatic organism.

Understanding and anticipating the consequences of numerous stressors in the face of change is one of the most important concerns in conservation and applied ecology which we require and should increase in order to improve the state of marine ecosystems ${ }^{(\mathbf{8}-10)}$. These alterations at the organism level are the primary and most sensitive stress reactions, but they may eventually alter community composition and interfere with ecosystem processes and services that support human wellbeing ${ }^{(11)}$.

Invertebrates from the sea are an important part of our diet since they contribute to our health intake, suitable source for bioactive chemical production, the occurrence of these chemicals is influenced not only by species, but also by environmental and seasonal conditions ${ }^{(12)}$. 
Anticancer compounds, antibiotics, and enzyme inhibitors have all been discovered using marine natural products, as evidenced by the hunt for anticancer chemicals, antibiotics, and enzyme inhibitors ${ }^{(12)}$.

Despite the present interest in bioactive marine chemicals, our understanding is restricted due to the field's recent history. Furthermore, there are challenges connected with data gathering and isolation ${ }^{(13)}$. In addition, finding novel medications to treat cancer remains a challenge ${ }^{(14)}$.

Because they provide food for other animals, interconnected with each other, and valuable to people, crustaceans and marine algae play an important part in the ecosystem's evaluation and productivity ${ }^{\left({ }^{(}\right)}$. As a result, analysing their distribution can help with general environmental monitoring, such as eutrophication, which is a symptom of environmental disturbance ${ }^{(10)}$. As a result, in recent years, the quest for crustaceans and marine algae has become increasingly essential. Because of their abundance of bioactive chemicals, marine macroalgae are one of nature's most biologically active resources ${ }^{(10)}$.

Antibacterial activity, antioxidant ability, antiinflammatory qualities, anticoagulant activity, antiviral activity, apoptotic activity, and prebiotic action have all been reported in marine macroalgae isolated compounds (15). Many seaweeds include bioactive components that prevent the growth of Gram positive and Gram negative bacterial pathogens ${ }^{(15)}$.

The importance of marine algae's pharmacological and economic qualities has prompted considerable research in recent years. Because marine organisms live in a very different ecology than terrestrial species, it's reasonable to assume that their secondary metabolites differ greatly (16). It is well known that it plays an essential role in the food web, productivity, and the overall marine ecology (15). Seaweeds are an excellent source of polysaccharides, tannins, flavonoids, phenolic acids, bromophenols, and carotenoids, as well as a variety of biological activities that express their solubility and polarity ${ }^{(17)}$.

Those designed researches to examine the link between them and other creatures were ignored when assessing the literature. As a result, the current study was created to accomplish the following objectives:

To learn more about the ecological link between marine algae and the Squall Mantis (Stomatopoda Squillidae), researchers conducted the following research.

By extracting, isolating, and identifying some bioactive marine natural compounds, as well as screening crude extracts for bioactivity to determine its effects on bacteria, fungi, and laryngeal cancer, an experiment was conducted to clarify the applied and medicinal value (Hep-II Cell line).

\section{MATERIALS AND METHODS Sampling:}

Seasonal sampling for Squilla mantis was carried out for this study over a one-year period, from January 2014 to January 2015, along the Southwestern coast of al max Bay,Mediterranean sea (Alexandriah Governorate). Specimens labelled as XL when collected on the beach. The obtained specimens were taken to a laboratory for analysis.

\section{Species identification of benthic crustaceans:}

The following sources were used to make the identification: Fishing-related FAO species identification sheets ${ }^{(\mathbf{1 8})}$.

\section{Identification of marine algae species:}

The samples were classified into species, according to Campbell ${ }^{(19)}$, Womersley ${ }^{(20,21)}$ and Aleem ${ }^{(22)}$.

\section{Bioactivity studies}

\section{1-Preparation of the volatile constituents:}

The volatile components were extracted using the E.P apparatus and hydro distillation. After saturation with sodium chloride, the distil oil was extracted with ether. The ether extract had been dried out. The solvent was extracted from anhydrous sodium sulphate at reduced pressure and at a low temperature. The oil was maintained in a cool, dark container according to Masada ${ }^{(23)}$.

\section{Identification of the constituents:}

Qualitative identification of different constituents were done by TLC, silica gel using benzene:EtAc (93:7) for one dimensional TLC, and $\mathrm{CHCL}_{3}: \mathrm{EtAc}$ (93:7) then benzene:EtAc (93:7) for two dimensional TLC. Vaniline $\mathrm{H}_{2} \mathrm{SO}_{4} 1 \%$ was used as a spray reagent. GC/MS was done using the apparatus GC/MS system $^{(23)}$. [Shimadzu GC/MSQP5050A.Software:class5000.Germany].

\section{2- Anti-microbial activity:}

The antimicrobial activity of the majority of the produced compounds was tested using the agar diffusion technique based on Cooper ${ }^{(24)}$.

\section{Microbial Organisms ${ }^{(24)}$ :}

\section{Escherichia coli (NCTC10418):}

Gram -ve straight rods, occurs in the lower part of the intestine.

\section{Bacillus subtilis (NCIMB8054):}

Endospore-forming, Gram +ve rods.

\section{Klebsiella pneumonia:}

Gram -ve bacteria, straight rods and normal in habitants of the intestinal tract and causes the urinary and respiratory tract infection. 


\section{Pseudomonas aeruginosa:}

Igram -ve rods, often can cause respiratory and urinary tract infection.

\section{Staphylococcus aureus (ATCC 29737):}

Gram +ve, potential pathogen causing a wild range of infections, e.g. pneumonia, various abscesses.

\section{Bacillus pumilus:}

Gram +ve bacteria, rods shape, endospore forming.

\section{Micrococcus luteus:}

Gram +ve bacteria, cocci primary habitat is mammalian skin.

\section{Candida albicans:}

Yeast-like microorganism pathogen causes Candidiasis.

\section{Aspergillus niger:}

Multi-cellular fungi, causes disturbance in respiratory system and lung.

\section{Aspergillus flavus:}

Multi-cellular fungi, causes disturbance in respiratory system and lung.

The inoculum prepared from a typical colony grown overnight on nutrient agar. Colony sampled less than 24 hours old was transferred to grow in a tube of sterile saline.

\section{3- Anti-Cancer Activity:}

\section{CELL CULTURE TECHNIQUES}

For making subculture of a cell line: Hep-II cell line, this approach was carried out according to Senthilraja and Kandasamy ${ }^{(26)}$ for larynx cancer.

\section{RESULTS}

Seasonal variation of marine algae:

The findings revealed a seasonal fluctuation in the percentage of marine algae present, which was reflected in the observed species numbers in the organism's habitat from one season to the next.

In order to monitor seasonal oscillations in the percentage of presence, the quantity of marine algae was seasonally recorded from January 2014 to January 2015, and was divided into three major divisions: Rhodophyceae (red algae), Phaeophyceae (brown algae), and Ulvophyceae (green algae).

\section{Rhodophyceae (red algae):}

In table (1), the observed species number differed from one season to another in the environment, the highest number was 22 recorded in spring, while the lowest was 13 recorded in winter. On the other hand the numbers of species was 21 and 19 in the summer and autumn respectively, with annual total number of species was 24 Species.
Table (1): Seasonal variation of (Rhodophyta)

\begin{tabular}{|c|c|c|c|c|}
\hline Rhodophyta & Winter & Spring & Summer & Autumn \\
\hline $\begin{array}{l}\text { Amphiroa } \\
\text { rigida }\end{array}$ & - & + & + & + \\
\hline $\begin{array}{l}\text { Ceramium } \\
\text { ciliatum }\end{array}$ & + & + & - & + \\
\hline $\begin{array}{l}\text { Ceramium } \\
\text { diaphanum }\end{array}$ & - & + & + & - \\
\hline $\begin{array}{l}\text { Ceramium } \\
\text { virgatum }\end{array}$ & - & + & + & + \\
\hline $\begin{array}{l}\text { Champia } \\
\text { parvula }\end{array}$ & + & + & + & + \\
\hline $\begin{array}{l}\text { Chondrophycus } \\
\text { papillosus }\end{array}$ & + & + & + & + \\
\hline $\begin{array}{l}\text { Corallina } \\
\text { officinalis }\end{array}$ & + & + & + & + \\
\hline $\begin{array}{l}\text { Dasya } \\
\text { hutchinsiae }\end{array}$ & - & + & + & + \\
\hline $\begin{array}{l}\text { Ellisolandia } \\
\text { elongata }\end{array}$ & - & - & - & + \\
\hline $\begin{array}{l}\text { Erythrotrichia } \\
\text { reflexa }\end{array}$ & + & + & + & - \\
\hline $\begin{array}{l}\text { Gelidium } \\
\text { crinale }\end{array}$ & + & + & - & - \\
\hline $\begin{array}{l}\text { Gracilaria } \\
\text { armata }\end{array}$ & + & + & + & + \\
\hline $\begin{array}{l}\text { Gracilaria } \\
\text { dura }\end{array}$ & + & + & + & + \\
\hline $\begin{array}{l}\text { Halymenia } \\
\text { elongata }\end{array}$ & - & + & + & + \\
\hline $\begin{array}{l}\text { Halymenia } \\
\text { floresii }\end{array}$ & - & + & + & + \\
\hline $\begin{array}{l}\text { Jania } \\
\text { adhaerens }\end{array}$ & + & + & + & + \\
\hline Jania rubens & + & + & + & + \\
\hline $\begin{array}{l}\text { Laurencia } \\
\text { papillosa }\end{array}$ & - & + & + & + \\
\hline Liagora viscida & + & + & - & + \\
\hline $\begin{array}{l}\text { Palisada } \\
\text { thuyoides }\end{array}$ & - & + & + & + \\
\hline $\begin{array}{l}\text { Polysiphonia } \\
\text { opaca }\end{array}$ & - & + & + & - \\
\hline $\begin{array}{l}\text { Pyropia } \\
\text { leucosticta }\end{array}$ & + & + & + & - \\
\hline $\begin{array}{l}\text { Scinaia } \\
\text { furcellata }\end{array}$ & - & + & + & + \\
\hline $\begin{array}{l}\text { Spyridia } \\
\text { filamentosa }\end{array}$ & + & - & + & + \\
\hline Seasonal total & 13 & 22 & 21 & 19 \\
\hline
\end{tabular}




\section{Phaeophyceae (brown algae):}

Table (2) shows species number of marine algae, which the minimum number was 11 recorded during winter, but the maximum number of species was 16 recorded during spring, with annual total number for species was 16; while summer and autumn season recorded 14 and 13 species respectively.

Table (2): Seasonal variation of (Phaeophyceae)

\begin{tabular}{|l|c|c|c|c|}
\hline Phaeophyceae & Winter & Spring & Summer & Autumn \\
\hline $\begin{array}{l}\text { Colpomenia } \\
\text { sinuosa }\end{array}$ & - & + & + & + \\
\hline $\begin{array}{l}\text { Cystoseira } \\
\text { myrica }\end{array}$ & + & + & + & + \\
\hline $\begin{array}{l}\text { Cystoseira } \\
\text { trinode }\end{array}$ & + & + & + & + \\
\hline $\begin{array}{l}\text { Dictyota } \\
\text { implexa }\end{array}$ & + & + & + & - \\
\hline $\begin{array}{l}\text { Halopteris } \\
\text { filicina }\end{array}$ & + & + & + & - \\
\hline $\begin{array}{l}\text { Halopteris } \\
\text { scoparia }\end{array}$ & - & + & + & + \\
\hline $\begin{array}{l}\text { Myrionema } \\
\text { conchicola }\end{array}$ & - & + & - & + \\
\hline $\begin{array}{l}\text { Nereia } \\
\text { filiformis }\end{array}$ & + & + & + & + \\
\hline $\begin{array}{l}\text { Padina } \\
\text { pavonica }\end{array}$ & + & + & + & + \\
\hline $\begin{array}{l}\text { Petalonia } \\
\text { fascia }\end{array}$ & + & + & - & + \\
\hline $\begin{array}{l}\text { Punctaria } \\
\text { latifolia }\end{array}$ & - & + & + & + \\
\hline $\begin{array}{l}\text { Sargassum } \\
\text { asperifolium }\end{array}$ & + & + & + & + \\
\hline $\begin{array}{l}\text { Sargassum } \\
\text { latifolium }\end{array}$ & - & + & + & + \\
\hline $\begin{array}{l}\text { Sphacelaria } \\
\text { cirrosa }\end{array}$ & + & + & + & + \\
\hline $\begin{array}{l}\text { Stilophora } \\
\text { tenella }\end{array}$ & + & + & + & - \\
\hline $\begin{array}{l}\text { Taonia } \\
\text { atomaria }\end{array}$ & + & + & + & + \\
\hline Seasonal total & $\mathbf{1 1}$ & $\mathbf{1 6}$ & $\mathbf{1 4}$ & $\mathbf{1 3}$ \\
\hline Annual total & & & $\mathbf{1 6}$ & \\
\hline
\end{tabular}

\section{Ulvophyceae (green algae):}

In table (3), the observed species number differed from one season to another in the environment. The highest number was 15 recorded in spring and summer, while the lowest was 12 recorded in winter, on the other hand the numbers of species was 14 in the autumn, with annual total number was 15 .

Table (3): Seasonal variation of (Ulvophyceae)

\begin{tabular}{|l|c|c|c|c|}
\hline Ulvophyceae & Winter & Spring & Summer & Autumn \\
\hline $\begin{array}{l}\text { Caulerpa } \\
\text { racemosa }\end{array}$ & + & + & + & + \\
\hline $\begin{array}{l}\text { Chaetomorpha } \\
\text { linum }\end{array}$ & + & + & + & + \\
\hline $\begin{array}{l}\text { Cladophora } \\
\text { gracilis }\end{array}$ & - & + & + & + \\
\hline $\begin{array}{l}\text { Codium } \\
\text { dichotomum }\end{array}$ & + & + & + & + \\
\hline $\begin{array}{l}\text { Codium } \\
\text { elongatum }\end{array}$ & + & + & + & + \\
\hline $\begin{array}{l}\text { Lychaete } \\
\text { pellucida }\end{array}$ & + & + & + & + \\
\hline Ulva clathrata & + & + & + & + \\
\hline $\begin{array}{l}\text { Ulva } \\
\text { compressa }\end{array}$ & + & + & + & + \\
\hline Ulva flexuosa & + & + & + & + \\
\hline $\begin{array}{l}\text { Ulva } \\
\text { intestinalis }\end{array}$ & - & + & + & + \\
\hline Ulva lactuca & + & + & + & + \\
\hline Ulva linza & + & + & + & + \\
\hline Ulva rigida & + & + & + & - \\
\hline $\begin{array}{l}\text { Ulvella } \\
\text { setchellii }\end{array}$ & - & + & + & + \\
\hline $\begin{array}{l}\text { Valonia } \\
\text { utricularis }\end{array}$ & - & + & + & + \\
\hline Seasonal total & $\mathbf{1 2}$ & $\mathbf{1 5}$ & $\mathbf{1 5}$ & $\mathbf{1 4}$ \\
\hline $\begin{array}{l}\text { Annual total } \\
\text { I5 }\end{array}$ & & $\mathbf{1 5}$ & \\
\hline
\end{tabular}




\section{Bioactivity studies}

Biochemical compounds from G C-Mass spectrometry:

The result in table (4) recorded the chemical compound (by G C-Mass spectrometry analysis of Squilla mantis shell extract, which extracted through hydro distillation, and consist of volatile constituents.

Table (4): the chemical composition of Squilla mantis shell extract

\begin{tabular}{|c|c|c|c|c|c|}
\hline $\mathrm{n}$ & R. T & $\begin{array}{l}\text { Molecular } \\
\text { weight }\end{array}$ & $\begin{array}{l}\text { Base } \\
\text { Peak }\end{array}$ & Another Fragment & Compound Name \\
\hline 1- & 19.825 & 190 & 175 & $\begin{array}{c}159-147-128-119-105- \\
91-80-41-57\end{array}$ & $\begin{array}{l}1,3 \text { - } \mathrm{Di}-\text { tert - } \\
\text { butylebenzene } \\
\mathrm{C}_{14} \mathrm{H}_{22}\end{array}$ \\
\hline $2-$ & 20.43 & 80 & 110 & $53-55-81-82-109$ & $\begin{array}{c}\text { Hydroquinone } \\
\mathrm{C}_{6} \mathrm{H}_{6 \mathrm{O}_{2}}\end{array}$ \\
\hline $3-$ & 30.527 & 290 & 43 & $\begin{array}{c}275-257-203-187-175- \\
161-137-123-109-95-81- \\
67-55-43\end{array}$ & $\begin{array}{l}\text { Manoyl Oxide } \\
\mathrm{C}_{20} \mathrm{H}_{34} \mathrm{O}\end{array}$ \\
\hline 4- & 30.527 & 264 & 43 & $\begin{array}{c}264-249-220-192-177- \\
153-140-136-123-109- \\
95-82-67-43\end{array}$ & $\begin{array}{c}\text { Ambreinolide } \\
\mathbf{C}_{17} \mathbf{H}_{28} \mathbf{O}_{2}\end{array}$ \\
\hline $5-$ & 30.142 & 270 & 157 & $\begin{array}{c}143-213-241-185-171- \\
115-227-97-227-85-129- \\
270-73-57-43\end{array}$ & $\begin{array}{c}\text { Heptadecanoic acid } \\
\mathrm{C}_{17} \mathrm{H}_{34} \mathrm{O}_{2}\end{array}$ \\
\hline 6- & 31.300 & 222 & 41 & $\begin{array}{c}152-179-110-96-82-55- \\
68-207\end{array}$ & $\begin{array}{c}\text { Ethanamine } \\
\mathrm{C}_{14} \mathrm{H}_{26} \mathrm{~N}_{2}\end{array}$ \\
\hline $7-$ & 32.983 & 298 & 43.05 & $\begin{array}{c}\text { 73-57-129-284-83-97- } \\
185-111-185241-17-199- \\
143 \\
\end{array}$ & $\begin{array}{l}\text { Nonadecanoic acide } \\
\mathrm{C}_{{ }_{19} \mathrm{H}_{38} \mathrm{O}_{2}}\end{array}$ \\
\hline 8- & 36.226 & 35 & 83 & $\begin{array}{c}140-154-168-182-196- \\
224-333-238-98-126- \\
55-70-47-113-83\end{array}$ & $\begin{array}{c}\text { N.9,10. } \\
\text { Epoxyoctadecanoyl } \\
\text { pyrro } \\
\mathrm{C}_{22} \mathrm{H}_{41} \mathrm{NO}_{2} \\
\end{array}$ \\
\hline 9- & 46.925 & 446 & 43.00 & 369 & $\begin{array}{c}\text { Mixture of 1,11- } \\
\text { DIPHENYL- } \\
\text { 1,2,3,4,8,9,10,11- } \\
\text { OCTHYDRO[1,4]DIO } \\
\text { XINO[2,3-G] } \\
\text { DIISA } \\
\text { C }_{30} \mathrm{H}_{26} \mathrm{~N}_{2} \mathrm{O}_{2}\end{array}$ \\
\hline 10- & 55.372 & 756 & 43.05 & $\begin{array}{c}299-756-55-69-83-105- \\
217-257-258-313-644\end{array}$ & $\begin{array}{c}\text { 12-Acetoxy-7,7-[6- } \\
\text { acetoxy-14-hydroxy-7- } \\
\text { oxo-5,8,11,13- } \\
\text { abietatetraen-11,12 } \\
\mathrm{C}_{44} \mathrm{H}_{52} \mathrm{O}_{11} \\
\end{array}$ \\
\hline 11- & 55.371 & 696 & 43 & $\begin{array}{c}255-496-698-377-577- \\
420-171-200-119-145- \\
95-55-69-185-43\end{array}$ & $\begin{array}{c}\text { Lanost-9 (11)-en-18-oic } \\
\text { acid } \\
\mathrm{C}_{39} \mathrm{H}_{53} \mathrm{BrO}_{6}\end{array}$ \\
\hline 12- & 57.2 & 516 & 731 & $\begin{array}{c}\text { 516-192-191-167-147- } \\
75-74-45\end{array}$ & $\begin{array}{c}\text { 5-(3,4-DIHYD5- } \\
\text { PHENYL } \\
\text { HYDANTOIN TMS } \\
\text { C }_{25} \mathrm{H}_{40} \mathrm{~N}_{2} \mathrm{O}_{4} \mathrm{~S}_{13}\end{array}$ \\
\hline
\end{tabular}




\section{Antimicrobial Activity}

Antimicrobial activity of Squilla mantis shell extract:

The result in table (5) indicated a significant difference between the groups which treated with shell extract (1.5, 2.5 , and $5 \mathrm{mg} / \mathrm{mL}$ ) compared to the control.

The result shows that, this extract of Squilla mantis has no high antibacterial activity against tested bacteria and fungus. While has moderate effect on Bacillus subtilis, Pseudomonas aeruginosa, Staphylococcus aureus, Bacillus pumilus and Candida albicans. In the same time, weak effect of the tested extract appears with tested bacteria (Escherichia coli, Klebsiella pneumonia and Micrococcus latus). This extract has weak effect with tested fungus (Aspergillus valves), and has no effect on (Aspergillus niger).

\section{$\underline{\text { Antimicrobial Activity }}$}

Table (5): Antimicrobial activity of Squilla mantis shell extract:

\begin{tabular}{|c|c|c|c|}
\hline & \multicolumn{3}{|c|}{$\begin{array}{c}\text { Concentrations } \\
(\mathrm{mg} / \mathrm{ml})\end{array}$} \\
\cline { 2 - 4 } Organisms & 1 & 2.5 & 5 \\
\hline Escherichia coli & + & + & + \\
\hline Bacillus subtilis & ++ & ++ & ++ \\
\hline Klebsilla pneumonia & + & + & + \\
\hline Pseudomonas aeruginosa & ++ & ++ & ++ \\
\hline Staphylococcus aureus & ++ & ++ & ++ \\
\hline Bacillus pumilus & ++ & ++ & ++ \\
\hline Micrococcus luteus & + & + & ++ \\
\hline Candida albicans & ++ & ++ & - \\
\hline Aspergillus niger & - & - & + \\
\hline Aspergillus valvus & + & + & + \\
\hline
\end{tabular}

The effect of Squilla mantis shell extract on (Hep-II) cell line (Microscopic examination):

The effect of Squilla mantis shell extract on larynx cancer cell line (Hep II) through culture assay (Figure 1) indicated a significant difference between the groups treated with shell extract $(20,40,80$, and $160,320 \mu \mathrm{g} / \mathrm{mL})$ compared to the control group.

The results revealed that the effect of Squilla mantis shell extract was clear especially with dilution 20, while with dilution 40 the effect of Squilla mantis shell extract was weak. In spite of the above mentioned results, the Squilla mantis shell extract didn't affect Hep-II cancer larynx cell line through culture assay with another dilution especially with 80, 160 and 320 dilutions, (Fig.1). 


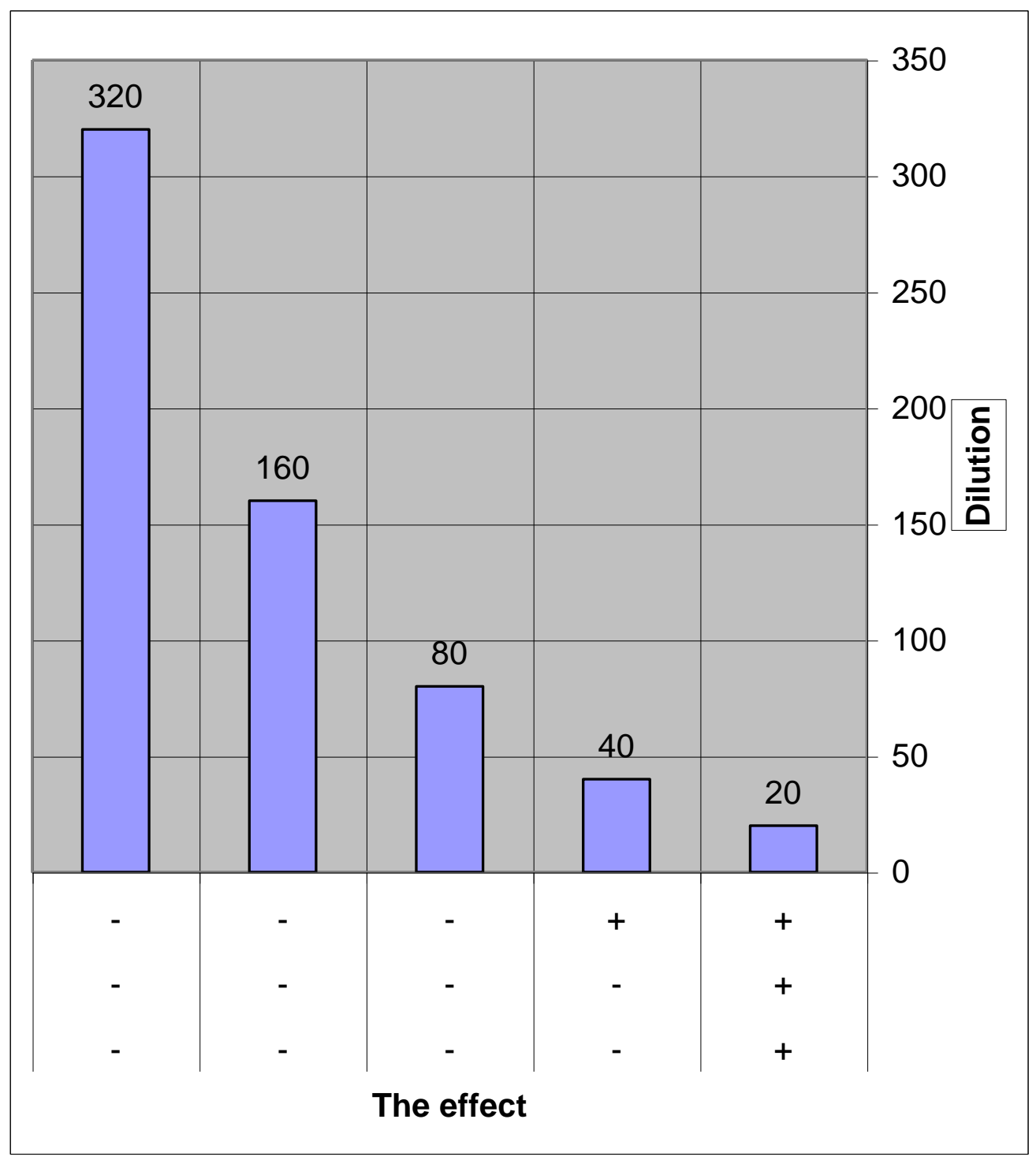

Figure (1): The effect of biological extract of Squilla mantis on (Hep- II) cell line (Microscopic examination).

The effect of biological extract of Squilla mantis on (Hep-II) cell line (Microscopic examination).

Tissue Culture Toxic Dose 50 (mg)

(The concentration of inhibition or toxicity)

The result revealed that toxicity of biological extracts using cell culture assay revealed that the effect of Squilla mantis shell crude extract showed toxic (or inhibition) effect on larynx cancer cell line (Hep-II). The toxic concentration for larynx cancer cell line (Hep-II) was $1.52 \mathrm{mg}$ through the shell crude extract of Squilla mantis.
Evaluation of viability \% of Hep-II cell line post treatment with studied Crustacean extracts using sufranin uptake assay as (MTT) uptake:

The effect of biological extracts on the Hep-II laryngeal cancer cell line (by cell viability) revealed a significant difference between the groups treated with shell extract (20,40,60, 80, and 160, 320, 640, 1280, and $2560 \mathrm{~g} / \mathrm{mL}$ ) and the control group (Table 6). 
Table (6): Evaluation of viability \% of Hep-II cell line post treatment with Squilla mantis crude shell extract using Cell Viability.

\begin{tabular}{|c|c|}
\hline $\begin{array}{c}\text { Dilution of } \\
\text { Squilla mantis shell } \\
\text { extract }\end{array}$ & $\begin{array}{c}\text { viability \% of } \\
\text { Hep- II cell }\end{array}$ \\
\hline $1 / 20$ & 46 \\
\hline $1 / 40$. & 77.6 \\
\hline $1 / 80$ & 100 \\
\hline $1 / 160$ & 100 \\
\hline $1 / 320$ & 100 \\
\hline $1 / 640$ & 100 \\
\hline $1 / 1280$ & 100 \\
\hline $1 / 2560$. & 100 \\
\hline
\end{tabular}

The effect of Squilla mantis shell extract was clear, especially with dilution 20, while it was weak with dilution 40 . At the same time, the Squilla mantis shell extract had no effect on the (Hep-2) cancer larynx cell line through culture assay with other dilutions, especially with 80,160, and 320 dilution, (Figures 2, 3, 4 and 5).

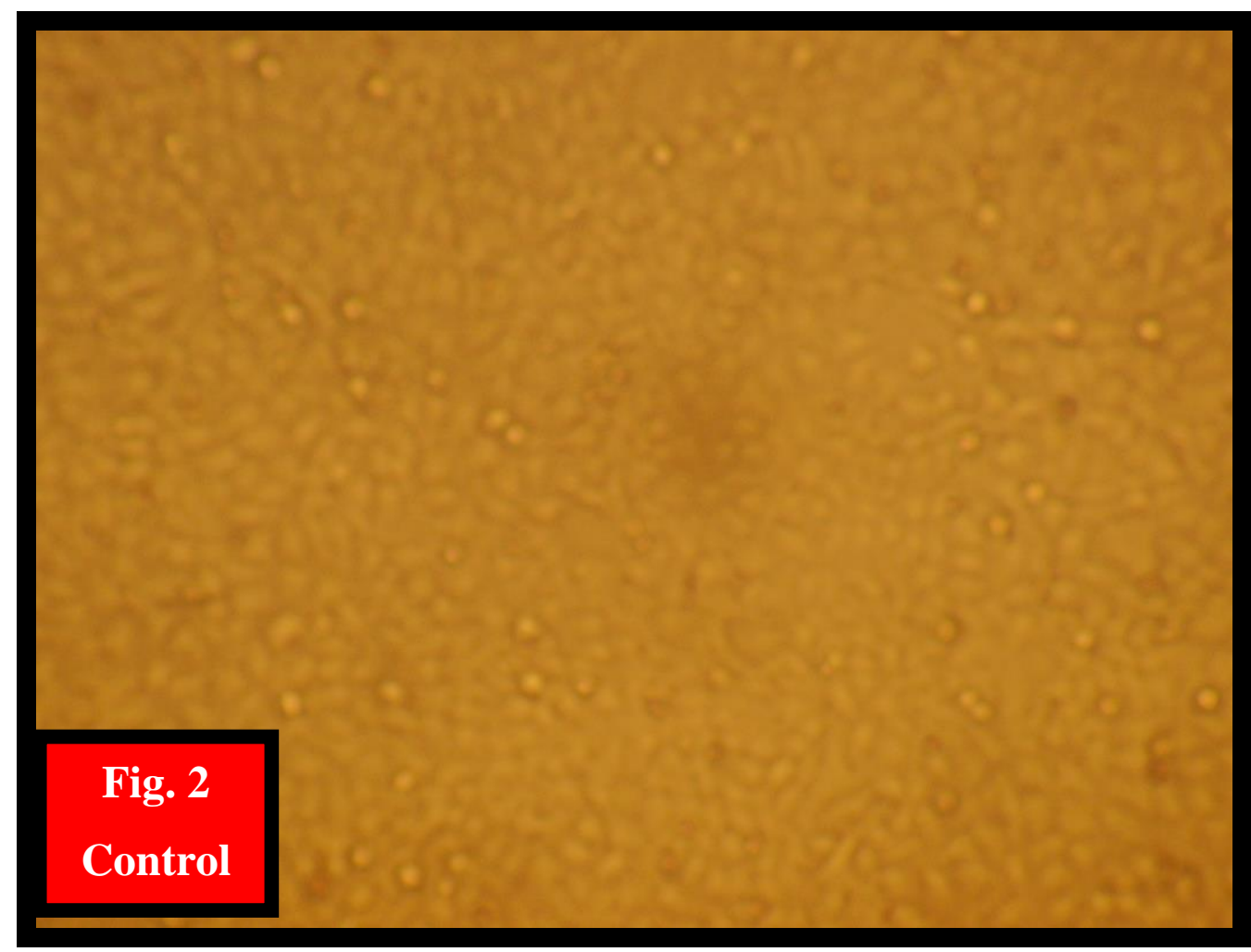

Figure (2): Control of larynx cancer (Hep-II cell line) 


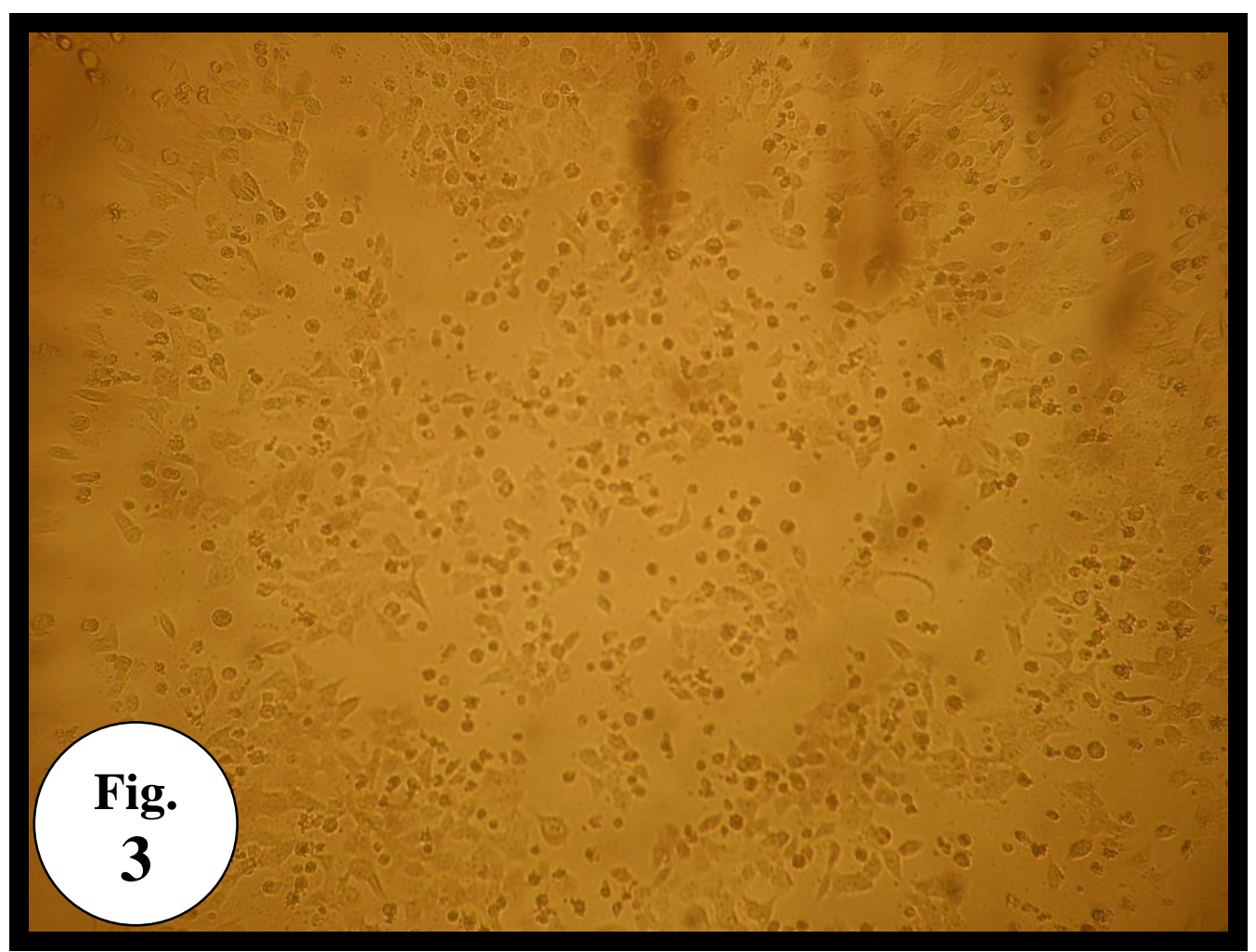

Figure (3): The effect of Squilla mantis shell extract (dilution 20) on larynx cancer cell line

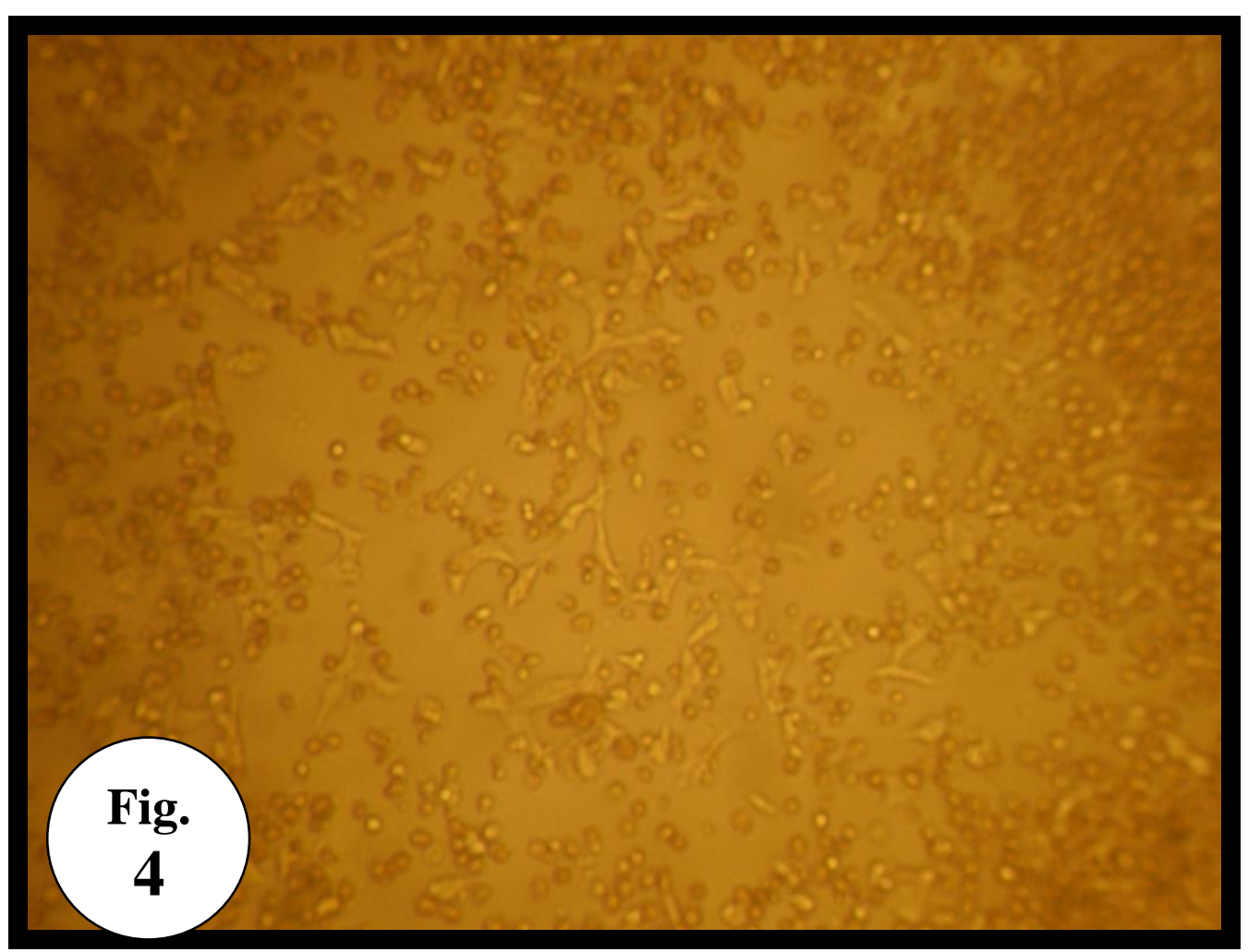

Figure (4): The effect of Squilla mantis shell extract (dilution 40) on larynx cancer cell line. 


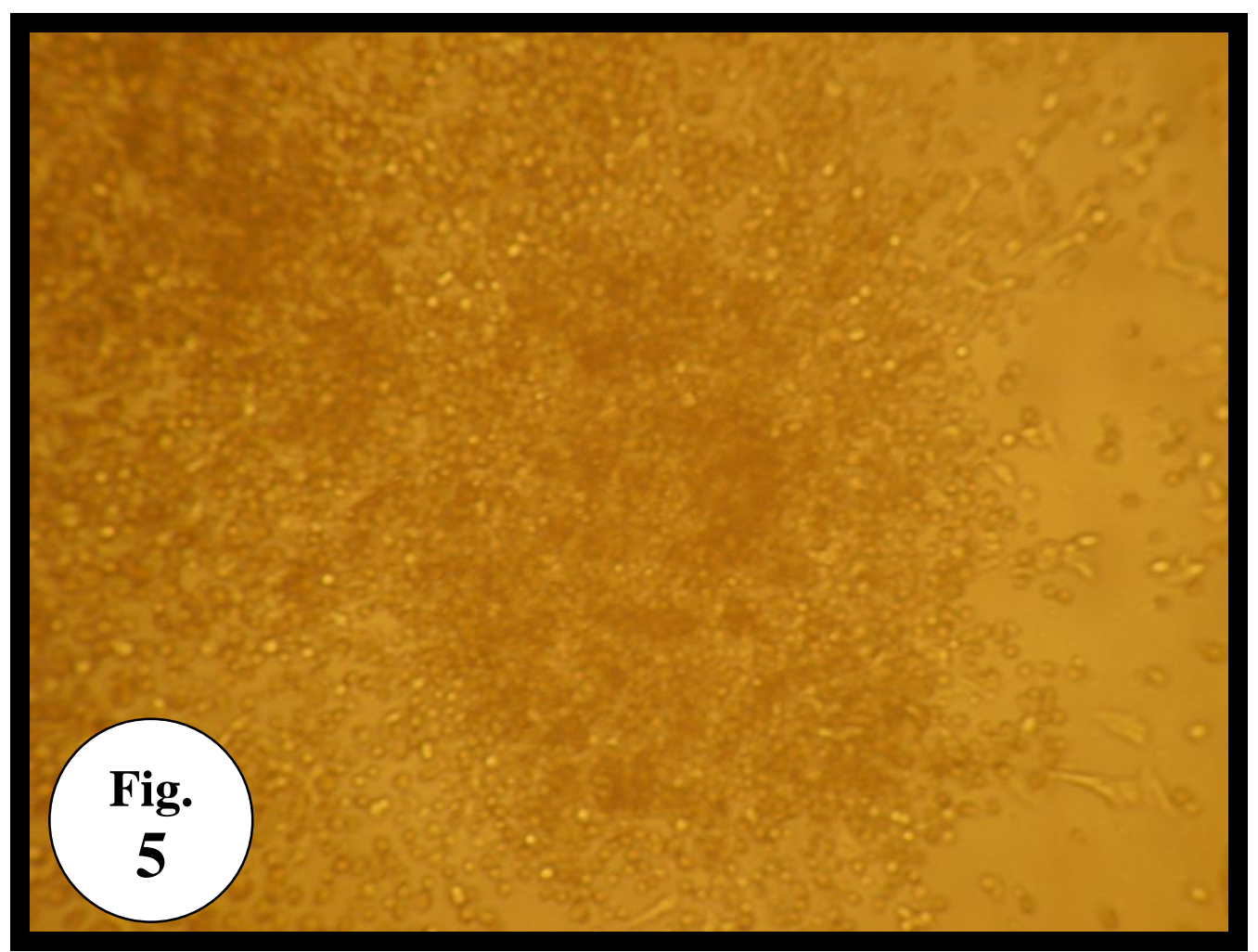

Figure (5): The effect of Squilla mantis shell extract (dilution 80) on larynx cancer cell line

\section{DISCUSSION}

One of ecologists' key objectives is to find elements that influence organisms. Due to the intricacy of the natural marine environment, this aim is challenging to attain ${ }^{(27)}$. From a scientific standpoint, understanding Squilla mantis (Stomatopoda - Squillidae) is critical. This species has a significant impact on the food chain, food web, marine ecosystem, as well as human diet and health ${ }^{(2)}$.

The state of the sea's environment is changing, which has an impact on organisms and all physical, chemical, and biological processes, for example Benedetta and Paul ${ }^{(28)}$ noted that the perceived abundance of mantis shrimp (Squilla mantis) has decreased significantly, and proof of a deficit has been discovered to supplement scientific knowledge about this. According to Abd-Elaziz (6), seasonal variations cause changes in environmental elements in maritime habitats, which affect the biochemical makeup of marine creatures. Seasonal changes in crustaceans may be due not just to changes in water temperature, but also to indirect effects on their food sources. Farina et al. ${ }^{(29)}$ agreed, stating that the feeding of some species can have a significant impact on ecological processes.

The current study demonstrated that there is differentiation in the environment surrounding the Squilla mantis by tracking changes in the percentages of marine algae as one of the main food and environment elements, which varied from season to season. The findings revealed seasonal variations in the diversity of marine macroalgae from the three primary divisions: Rhodophyceae (red algae), Phaeophyceae (brown algae), and Ulvophyceae (green algae). In the environment, the observed species number varied from one season to the next, with the highest number recorded in spring and the lowest in winter; on the other hand, the numbers of species in the summer were typically higher than those in the autumn, with annual total numbers of (24, 16, and 15) species for Rhodophyceae, Phaeophyceae, and Ulvophyceae, respectively, while the total number of all species was 55 species.

The findings revealed a significant seasonal variation in the percentage of marine algae, which was mirrored in the number of species recorded for each season, and thus on the total number of species observed in the organism's environment. It is clear that the total number of species observed in the environment of the organism under study is related to productivity, growth, food availability, and environmental yield. This is consistent with the

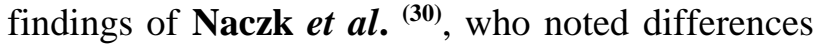
in biodiversity, diet nutrient composition (31), surrounding medium, and other environmental factors associated with seasonal variation ${ }^{(8)}$.

Because the elements are numerous and overlap, this study attempted to determine the magnitude of their impact and which are more influential. Increases in sea surface temperature (SST), changes in water mass circulation and mixed layer depths, changed primary production, or ocean acidification1-3 are all mentioned by Vicenç $\boldsymbol{e t}$ al. 
(32). Climate change is also increasing the frequency and intensity of marine heat waves ${ }^{(34)}$.

Seasonal changes in physical characteristics in estuarine ecosystems are influenced by changes in freshwater and fertiliser inputs. As a result, when compared to other marine species, crustaceans are peculiar. This is because they respond to salinity variations in a wide range of ways, from those that can regulate against external changes to those that just conform. Crustacean studies can thus give an excellent chance for researchers to investigate the relationship between environmental variability and the ability to endure ocean acidification, which has lately been discussed in the literature ${ }^{(33)}$.

The results of this study are similar to those of prior studies, and they confirm previous findings about many ecological parameters, seasonal variation, and its impact on organisms, the food cycle, and the marine ecosystem, for example, Velasco et al. ${ }^{(7)}$. Many of the physiological aspects that influence the performance of aquatic organisms are affected by changes in environmental conditions linked with global change at the organism level ${ }^{(6)}$. In addition, the $\mathrm{pH}$ of natural waters plays a significant role in the chemical and biological systems ${ }^{(7)}$. The photosynthetic activity of aquatic flora, temperature, salinity, and the amount of organic components all have a significant impact ${ }^{(6)}$.

Crude extract from the shell of Squilla mantis gives good effect on microbiological species (Bacteria and Fungi): Bacillus subtilis, Pseudomonas aeruginosa, staphylococcus aureus, Bacillus pumilus, Candida albican, and gives mixed results with others, according to the first record via the present work.

Thirunavukkarasu et al. ${ }^{(34)}$ investigated the production of chitin in two marine stomatopods, claiming that just a few studies on crustacean stomatopods relevant to chitin extraction are accessible. Chitin was isolated from marine crustacean shell debris by Mohan et al. ${ }^{(35)}$ (Shrimp, crab, squilla and lobster). According to El-Mehdawy et al. ${ }^{(36)}$, shrimp shell extract (Penaeus semisulcatus) includes a significant amount of chitosan and chitin, both of which have an inhibitory impact on bacteria (ve Gram).

On the other hand, Nasef (14) found that shrimp shell extract includes a significant amount of chemical compounds that hinder the growth of bacteria (-ve and +ve Gram) and fungus ${ }^{(37)}$. This is consistent with the findings of the current investigation. On the other hand, crude extract, was found to have a positive effect on the Hep-II cell line (Cancer larynx) in the current study, especially at high concentrations. Crab shell extract suppressed the proliferation of a breast cancer cell line in a dose and time-dependent manner, according to Leila et al. ${ }^{(38)}$.

The findings of this study are similar to those of prior studies such as Nasef ${ }^{(14)}$ Thirunavukkarasu $e t$ al. ${ }^{(34)}$, Mohan et al. ${ }^{(35)}$ and El-Mehdawy et al. ${ }^{(36)}$. and they match previous findings on various cancer cell lines that were produced in collaboration with marine biologists and ecologists as an integrated element of marine natural products. Although the results of this study provide detailed information about the biochemical composition of Squilla mantis, the most common marine benthic crustacean in the Mediterranean Sea, they also reflect the impact of environmental factors on the biochemical composition of one marine benthic crustacean, which calls for more research and studies.

Finally, we need additional research into the effects of the environment on crustaceans utilising single and double variable trials. These experiments are usually carried out to gain a better understanding of biological processes.

It's time to take a more comprehensive approach to understanding environmental variability and climate change, as well as their consequences, by putting large-scale, long-term datasets to work, as well as large-scale oceanographic and biophysical modelling, to start developing a workable hypothesis.

\section{REFERENCE}

1. Whiteley N (2011): Physiological and ecological responses of crustaceans to ocean acidification. Marine Ecology Progress Series, 430: 257-271.

2. Akram M, Mohammad I, Towhid H, Marjia S, Nurul H, Robiul H (2020): Biochemical composition and caloric values of different body segments of the female mangrove crab (Scylla olivacea). Egyptian Journal of Aquatic Biology \& Fisheries._24(7): 817 - 823.

3. Mohamed M (2006): Chemical studies of the interstitial water of Abu-Qir Bay of Alexandria. Egypt. M.Sc. Thesis, Chem. Dep., Fac. Of Science Al-Azhar University, Pp 279.

4. Davenport L, Gruffydd L, Beaumont A (2009): An apparatus to supply water of fluctuating salinity and its use in a study of the salinity tolerances larvae of the scallop Pecten maximus L. J. Mar. Biol. Ass. U. K., 55: 391 409.

5. Bridget S, Caleb G, Jennifer D , Adrian L (2014): Environmental effects on fished lobsters and crabs. Rev Fish Biol Fisheries., 24:613-638

6. Abd-Elaziz A (2009): Biological studies on some benthic crustaceans from Abu-Qir Bay (Alexandria, Egypt). Ph.D. Sc. Thesis in Marine Ecology, Faculty of Science, AlAzhar University. Pp 316.

7. Velasco J, Gutierrez C, Botella-Cruz M, SanchezFerna D, Arribas P, Carbonell J, Millan A, Pallares S (2019): Effects of salinity changes on aquatic organisms in a multiple stressor context. Phil. Trans. R. Soc. B374: 20180011.http://dx.doi.org/10.1098/rstb.2018.0011

8. Côté I, Darling E, Brown C (2016): Interactions among ecosystem stressors and their importance in conservation. Proc. R. Soc. B283, 1-9. doi:10.1098/rspb.2015.2592

9. Schafer R, Piggott $\mathbf{J}$ (2018): Advancing understanding and prediction in multiple stressor research through a mechanistic basis for null models. Glob. Chang. Biol., 24: $1817-1826$. 
10. Crain C, Kroeker K, Halpern B (2008): Interactive and cumulative effects of multiple human stressors in marine systems. Ecol. Lett.,11: 1304-1315.

11. Gutierrez C , Novas C et al. (2019): Do all roads lead to Rome? Exploring community trajectories in response to anthropogenic salinization and dilution of rivers. Phil. doi:10.1098/rstb.2018.0009

12. Abouzeed A, Omayma E, Ibrahim S, Attia R, Aboulyazeed A (2015): Production and evaluation of some bioactive compounds extracted from Squilla (Oratosquilla massavensis) shells. American Journal of Life Sciences, 3(6-1): 38-44.

13. Venugopal V , Shahidi F (1998): Structure composition of fish muscle. Food Rev International., 12 (2): $175-197$.

14. Nasef A (2016): Seasonal variation of biochemical composition of Penaeus Semisulcatus (Decapoda: Penaeidae) and the effect of its shell extract on bacteria, fungi and cancer. The Egyptian Journal of Hospital Medicine, 65: 598-610.

15. Ibraheem I, Elaziz B, Moawad A, Hassan H, Mohamed A, Abdel-Raouf N (2017): Antimicrobial and anti-inflammatory effects of two different marine red algae species collected from Quseir, the Red Sea, Egypt. Asian Journal of Cell Biology, 2(223):1-10.

16. Morsy G, Bekhet E, Mohamed E (2020): Phytochemical screening for antibacterial compounds of some seaweed from coastal area of Abu-Qir, Alexandria, egypt phytochemical screening for antibacterial compounds of some seaweed from coastal area of AbuQir, Alexandria. Egyptian J. of Phycol., 19: 47-57.

17. El-Chaghaby G, Rashad S, Abdel-Kader S, Rawash E, Moneem M (2019): Assessment of phytochemical components, proximate composition and antioxidant properties of Scenedesmus obliquus, Chlorella vulgaris and Spirulina platensis algae extracts. Egyptian Journal of Aquatic Biology \& Fisheries, 23(4): 521 - 526.

18. Anone (1973): FAO species identification sheets for fishery purposes. Mediterranean and black Sea (Fishing areas 37). https://agris.fao.org.

19. Campbell A (1982): The flora and fauna of the Mediterranean Sea. The Hamlyn publishing group limited, London, Pp 320.

20. Womersley H (1984): The marine benthic flora of southern Australia. Part I (Gout Printer: Adelaide). https://www.awe.gov.au/science-research.

21. Womersley H (1987): The marine benthic flora of southern Australia. Part II (Gout Printer: Adelaide). https://www.awe.gov.au/science-research.

22. Aleem A (1993): The marine algae of Alexandria Egypt. Ed. University of Alexandria Egypt., Pp 155.

23. Masada Y (1976): Analysis of essential oil by Gas Chromatography and Mass Spectrometry. John Wiley \& Sons, Inc. https://lib.ugent.be/catalog.
24. Cooper $R$ (1972): Analytical Microbiology. F.W. Kavanageh, (E.D), Vol: I, II, Academic press, New York and London.

25. Pitt T, Barer M (2012): Classification, identification and typing of micro-organisms. Elsevier publications health, doi: 10.1016/B978-0-7020-4089-4.00018-4.

26. Senthilraja $P$ and Kandasamy $K$ (2015): In vitro cytotoxicity MTT assay in Vero, HepG2 and MCF -7 cell lines study of Marine Yeast. Journal of Applied Pharmaceutical Science, 5(3):080-084.

27. Lee $S$ (2008): Mangrove macrobenthos: Assemblages, services, and linkages. Journal of Sea Research, 59: 1629.

28. Benedetta V , Paul G (2021): Fishers' knowledge detects ecological decay in the Mediterranean Sea. Ambio., 50:1159-1171

29. Farina J, Castilla J , Ojeda F (2003): The "idiosyncratic effect of a "sentinet' species on contaminated rocky intertidal communities. Scalagical Applications, 3(6):1533 -1552 .

30. Naczk M, Williams J, Brennan K et al. (2004): Compositional characteristics of green crab (Carcinus maenas). Food Chem., 88: 429-434.

31. Banu S, Hareesh K, Reddy M (2016): Evaluation of nutritional status of Penaeid Prawns through proximate composition studies. International Journal of Fisheries and Aquatic Studies, 4(1): 13-19

32. Vicenç M, Miquel P, Andrés O et al. (2021): Projected effects of ocean warming on an iconic pelagic fish and its fishery. Scientific Reports, 11:8803,

33. Frölicher T, Fischer E, Gruber N (2018): Marine heatwaves under global warming. Nature,560:360 364

34. Thirunavukkarasu N, Dhinamala $R$,Moses I (2011): Production of chitin from two marine stomatopods Oratosquilla spp. (Crustacea), J. Chem. Pharm. Res., 3(1):353-359.

35. Mohan K, Muralisankar $\mathbf{T}$, Jayakumar $\mathbf{R}$ and Rajeevgandhi C (2021): A study on structural comparisons of $\alpha$-chitin extracted from marine crustacean shell waste. https://doi.org/10.1016/j.carpta.2021.100037

36. El-Mehdawy A, Abd El-Aziz A, Abo Seena F et al. (2015): Study of some rotistes using nano-techinques, M.Sc thesis, PP. 179 Zoology Dep., Faculty of Science AlAzhar University, Cairo, Egypt.

37. Kiran N, Siddiqui G, Khan AN, Ibrar K, Tushar P (2014): Extraction and screening of bioactive compounds with antimicrobial properties from selected species of mollusk and crustacean. J Clin Cell Immunol., 5: 189.

38. Leila $R$, Zahra $R$, Pegah $M$ et al. (2014): Antiproliferatory effects of Crab shell extract on breast cancer cell line (MCF7). J Breast Cancer, 17(3): 219-225. 